\title{
Pengaruh Kepemimpinan Dan Kompensasi Terhadap Loyalitas Agen Dan Dampaknya Terhadap Kinerja Agen Pada PT. BNI Life Insurance Di Kantor Pemasaran Agency II
}

\author{
Elida Gultom \\ Sekolah Tinggi Ilmu Ekonomi Riau (STIER) \\ Jln. HR. Subrantas 57 Panam Pekanbaru 28293 Telp. (0761) 63237 \\ E-mail : gultom-elida@yahoo.com
}

\begin{abstract}
This study aims to determine the effect of leadership, compensation and agent loyalty against agent performance on PT. BNI Life Insurance at Marketing Agency II Office. The population in this study are all agents have the AAJI license certification with work tenure $>1$ year on PT. BNI Life Insurance at Marketing Agency II Office consisting of 15 Cities in Indonesia with a total of as many agents as 785 people. The sampling in this study were taken by disproportionate stratified random sampling, using the formula of Taro Yamane in order to obtain as many as 89 people. The method used is quantitative method with data collection instruments that form questionnaire Likert scale models. Hypothesis testing is done via Path analysis techniques assisted with data processing devices Statistical Package of Social Science (SPSS) 17.0. Sub-structure analysis results 1 show that leadership and compensation significant effect on the loyalty of agents with contributions (donations) leadership to the loyalty of agents by $85.9 \%$ and $14.5 \%$ of compensation. While the SubStructure 2 shows that leadership, compensation and agent loyalty significant effect on the performance of agents. As for the contribution of leadership (X1) on the performance of the agent (Y) is expressed with a path coefficient of $27.3 \%$. compensation (X2) by $20.4 \%$ and loyalty agent (X3) amounted to $52.3 \%$.
\end{abstract}

Keywords: Leadership, Compensation, Loyalty and Employee Performance

Setiap tahun pertumbuhan rata-rata premi asuransi di Indonesia sebesar 23\%, sementara pertumbuhan aset dari perusahaan asuransi tersebut sekitar $25 \%$. Dengan pertumbuhan industri yang semakin pesat setiap tahunnya diharapkan perkembangan perusahaan asuransi di Indonesia bisa menjadi penggerak perekonomian Indonesia lebih baik.

Berdasarkan laporan yang telah dipublikasikan oleh Asosiasi Asuransi Jiwa Indonesia (AAJI) mencatat pada tahun 2011 lalu, investasi perusahaan asuransi jiwa sebesar Rp 200,39 triliun atau naik $20 \%$ dibanding periode yang sama tahun 2010 sedangkan total pendapatan premi tahun 2013 sebesar Rp 113,93 trilun, atau tumbuh 5,8\% dari total premi tahun 2012.

Perusahaan asuransi jiwa merupakan perusahaan yang bergerak dibidang jasa, dimana jasa yang diberikan oleh perusahaan asuransi jiwa adalah berupa jasa proteksi atau perlindungan terhadap kerugian keuangan yang diakibatkan oleh kematian, cacad, biaya kesehatan dan menua sehingga perusahaan dalam memasarkan produknya mengalami kesulitan karena produk yang akan dipasarkannya itu bukan merupakan produk yang dapat dilihat atau berwujud.

Didalam perusahaan asuransi yang menjadi titik fokus dari seluruh aktivitas pemasaran yang mendistribusikan produkproduk yang akan dijual dengan cara penjualan langsung (direct selling) adalah departemen pemasaran dan keagenan. Hubungan kerja antara agen asuransi (perseorangan) dan perusahaan asuransi (badan hukum) terdapat beberapa konsep yang antara lain: (1) Agen sebagai employee, dengan demikian hubungan kerjanya sebagaimana layaknya employee dan employer, (2) Agen sebagai partner/mitra kerja, dengan demikian statusnya bukan sebagai employee tetapi sebagai mitra yang kedudukannya setara.

Sebagaimana Ikatan Agen Asuransi Indonesia (IAAI) menjelaskan bahwa: 
(1)Status agen asuransi bukan sebagai karyawan telah disebutkan dalam kontrak kerja. Mereka bekerja dengan biaya operasional ditanggung sendiri (2) Agen asuransi tidak dapat dimasukkan sebagai karyawan. Sebab, karakteristik ini tidak sama. Bahkan, posisi agen dianggap sandy lemah

Berdasarkan pengamatan peneliti, saat ini hampir seluruh perusahaan asuransi menerapkan konsep agen sebagai mitra kerja. Hal ini mengakibatkan tingkat turnover agen pada perusahaan asuransi sangat tinggi. Sementara dalam teori manajemen menerangkan bahwa tingkat perpindahan karyawan yang tinggi akan merugikan perusahaan baik dari segi waktu, tenaga maupun biaya. Hal ini disebabkan karena perusahaan akan melakukan penarikan karyawan baru lagi, menyeleksi, melatih, dan mengembangkan karyawan baru yang akan menggantikan posisinya.

Disisi lain agen asuransi juga memiliki otonomi profesional yang tinggi. Kesuksesannya menjalani karir tergantung seberapa bagus dan ulet agen tersebut menjalani profesinya. Semakin baik prestasinya, semakin besar pendapatan yang diraih. Hal ini disebabkan adanya sistem kompensasi yang menggiurkan yang ditawarkan oleh perusahaan asuransi. Suksesnya agen asuransi, selain karena kompensasi yang mengiurkan juga karena di pengaruhi adanya supervisi yang bagus dari pimpinanya sehingga membuat agen tersebut tetap bertahan pada perusahaan. Maka tidak heran jika dalam perusahaan asuransi dalam istilah peneliti seringkali terjadi turnover satu pohon artinya jika seorang manager merasa sudah tidak nyaman atau ada tawaran yang menggiurkan dari perusahaan asuransi lain, maka manager tersebut akan pindah membawa timnya dan hal ini akan berpengaruh terhadap kinerja perusahaan.

Pada awal tahun 2013, kasus seperti ini juga pernah terjadi pada PT BNI Life Insurance, ada risighn satu pohon yang mengakibatkan secara tidak langsung berdampak terhadap kinerja perusahaan.
Karena terkadang nasabahnya juga ikut ditarik dan dibawa ke perusahaan yang baru.

PT. BNI Life Insurance tidak hanya menghadirkan produk-produk tradisional namun juga menghadirkan beberapa produk baru lainnya antara lain produk asuransi pesangon dan produk asuransi yang menggabungkan proteksi dengan investasi (unit link).

Sampai akhir 31 Desember 2013, total aset PT. BNI Life Insurance telah mencapai lebih dari $\mathrm{Rp} 7,7$ triliun dengan pendapatan premi lebih dari $\operatorname{Rp} 4,1$ triliun. Secara konsisten dan terus menerus PT BNI Life Insurance berupaya mengembangkan market share dengan tetap mempertahankan Risk Based Capital (RBC) sesuai dengan peraturan pemerintah. Adapun jumlah Kantor Cabang Pemasaran Agency II PT. BNI Life Insurance di seluruh Indonesia yaitu sebagai berikut :

Tabel.1 Jumlah Kantor Cabang Pemasaran Agency II PT.BNI Life Insurance di Seluruh Indonesia

\begin{tabular}{|c|l|l|}
\hline No & Kantor Pemasaran & \multicolumn{1}{|c|}{ Provinsi } \\
\hline 1 & Pekanbaru & Riau \\
\hline 2 & Yogyakarta & DI Yogyakarta \\
\hline 3 & Surabaya & JawaTimur \\
\hline 4 & Bandung & Jawa Barat \\
\hline 5 & Slipi & Jakarta \\
\hline 6 & Samarinda & Kalimantan Timur \\
\hline 7 & Makassar & Sulawesi Selatan \\
\hline 8 & Solo & Jawa Tengah \\
\hline 9 & Aceh & DI Aceh \\
\hline 10 & Palembang & Sumatera Selatan \\
\hline 11 & Semarang & Jawa Tengah \\
\hline 12 & Bengkulu & Bengkulu \\
\hline 13 & Garut & Jawa Barat \\
\hline 14 & Kediri & Kediri \\
\hline 15 & Medan & Sumatera Utara \\
\hline
\end{tabular}

Sumber : PT. BNI Life Insurance, 2014

Berikut Data jumlah agen pada Pada Kantor Cabang Pemasaran Agency II PT.BNI Life Insurance. 
Tabel 2 Jumlah Agen Pada Kantor Cabang Pemasaran Agency II PT.BNI Life Insurance

\begin{tabular}{|c|l|c|c|}
\hline No & \multicolumn{1}{|c|}{ Jabatan } & $\begin{array}{c}\text { Jumlah } \\
\text { (orang) }\end{array}$ & $\begin{array}{c}\text { Persentase } \\
(\%)\end{array}$ \\
\hline 1 & Regional Director & 1 & 0,13 \\
\hline 2 & Regional Manajer & 3 & 0,38 \\
\hline 3 & Distrik Manajer & 15 & 1,91 \\
\hline 4 & Branch Manajer & 45 & 5,73 \\
\hline 5 & Sales Manajer & 151 & 19,24 \\
\hline 6 & $\begin{array}{l}\text { Financial } \\
\text { Consultan }\end{array}$ & 570 & 72,61 \\
\hline \multicolumn{2}{|c|}{ Total } & 785 & 100 \\
\hline
\end{tabular}

Sumber : PT. BNI Life Insurance, 2014

Secara umum seorang karyawan mempunyai banyak motif yang melatarbelakangi dirinya untuk mau bekerja, diantaranya adalah untuk dapat mencukupi kebutuhan hidup sehari-hari, untuk memperoleh pengakuan, sebagai simbol prestise di masyarakat dan lain-ain. Bagi perusahaan, karyawan adalah salah satu sumber daya yang amat dibutuhkan untuk mencapai tujuan perusahaan. Sebaliknya, bagi karyawan yang mempunyai berbagai macam kebutuhan, perusahaan juga merupakan salah satu tempat yang dapat memuaskan kebutuhannya.

Kompensasi merupakan imbalan yang diberikan oleh perusahaan kepada karyawan, atas jasanya dalam melakukan tugas, kewajiban dan tanggungjawab yang dibebankan kepadanya dalam rangka pencapaian tujuan perusahaan. Kompensasi merupakan aspek penting dalam menentukan kinerja karyawan dalam perusahaan. Faktor penting yang mendorong karyawan loyal pada perusahaan adalah kompensasi maupun pengupahan. Berikut data upah/komisi yang diterima oleh Kantor Pemasaran Agency I dan Agency II tiga (3) tahun terakhir yaitu dari tahun 2011 - 2013 sebagai berikut:

Tabel. 3 Upah/Komisi Tahun 2011- 2013 Pada Kantor Pemasaran Agency I dan II PT.BNI Life Insurance

\begin{tabular}{|c|c|c|c|}
\hline \multirow{2}{*}{ Thn } & \multicolumn{2}{|c|}{ Komisi/ Upah (Rp) } & \multirow{2}{*}{ Jumlah (Rp) } \\
\cline { 2 - 3 } & Agency I & Agency II & \\
\hline 2011 & 5.549 .614 .075 & 4.050 .272 .765 & 9.599 .886 .840 \\
\hline 2012 & 6.608 .966 .198 & 5.332 .748 .903 & 11.941 .715 .101 \\
\hline 2013 & 6.862 .392 .957 & 5.160 .644 .196 & 12.023 .037 .153 \\
\hline Total & 19.020 .973 .230 & 14.543 .665 .864 & 33.564 .639 .094 \\
\hline
\end{tabular}

Sumber: PT. BNI Life Insurance, 2014.
Pekerja merupakan aset perusahaan yang selalu dimonitor kebutuhan dan keinginannya sehingga diharapkan mampu menghasilkan prestasi kerja yang baik dan akhirnya dapat mencapai tujuan perusahaan secara efisien dan efektif. Hal ini penting karena berkembang atau tidaknya perusahaan tergantung pada kemampuan dan kerjasama antara pemimpin dan karyawannya. Berikut data agen, tiga (3) tahun terakhir antara tahun 2011- 2013 pada PT BNI Life Insurance.

Tabel 4 Data Agen Tahun 2011 - 2013 Pada Kantor Pemasaran Agency I dan II PT.BNI Life Insurance

\begin{tabular}{|c|c|c|c|c|}
\hline \multirow{2}{*}{ NO } & & \multicolumn{2}{|c|}{ Jumlah Agen } & \\
\cline { 3 - 4 } & \multirow{2}{*}{ Tahun } & Agency I & Agency II & \multirow{2}{*}{ Jumlah } \\
\hline 1 & 2011 & 660 & 567 & 1.227 \\
\hline 2 & 2012 & 758 & 625 & 1.383 \\
\hline 3 & 2013 & 923 & 785 & 1.708 \\
\hline
\end{tabular}

Sumber: PT. BNI Life Insurance, 2014.

Loyalitas seorang karyawan tidak hanya diukur dari kesetiaannya terhadap perusahaan tapi yang lebih penting, karyawan dapat memberikan kontribusi berarti bagi perusahaan.

Tabel 5 Jumlah Perolehan Premi Tahun 2011 - 2013 Pada Kantor Pemasaran Agency I dan II PT.BNI Life Insurance

\begin{tabular}{|c|c|c|r|}
\hline \multirow{2}{*}{ Thn } & \multicolumn{2}{|c|}{ Premi (Rp) } & \multirow{2}{*}{ Jumlah } \\
\cline { 2 - 3 } & Agency I & Agency II & \\
\hline 2011 & 52.549 .614 .075 & 40.502 .727 .656 & 93.052 .341 .731 \\
\hline 2012 & 44.608 .966 .198 & 53.320 .748 .903 & 97.929 .715 .101 \\
\hline 2013 & 55.862 .392 .957 & 45.160 .644 .196 & 101.023 .037 .153 \\
\hline Total & 153.020 .973 .230 & 138.984 .120 .755 & 208.257 .986 .385 \\
\hline
\end{tabular}

Sumber: PT. BNI Life Insurance, 2014.

Kompensasi dan loyalitas karyawan mempunyai pengaruh timbal balik. Kompensasi dapat meningkatkan loyalitas karyawan dan loyalitas dapat meningkatkan kompensasi karyawan, sebab loyalitas dapat meningkatkan kinerja karyawan. Karyawan yang loyal akan berusaha melaksanakan pekerjaannya secara giat, cepat dan baik.

Menurut Rivai dan Jauvani, (2011:548) kinerja merupakan perilaku nyata yang ditampilkan setiap orang sebagai prestasi kerja yang dihasilkan oleh karyawan sesuai dengan peranannya dalam perusahaan. 
B. Siswanto Sastrohadiwiryo (2005: 235), Mengatakan pada umumnya unsurunsur yang perlu diadakan penilaian dalam proses penilaian kinerja adalah kesetiaan, prestasi kerja, tanggung jawab, ketaatan, kejujuran, kerjasama, prakarsa, dan kepemimpinan. Adapun penjelasannya sebagai berikut :

\section{1) Kesetiaan}

Kesetiaan adalah tekad dan kesanggupan mentaati, melaksanakan dan mengamalkan sesuatu yang ditaati dengan penuh kesadaran dan tanggung jawab.

2) Prestasi kerja

Yang dimaksud dengan hasil kerja adalah kinerja yang dicapai oleh seorang tenaga kerja dalam melaksanakan tugas dan pekerjaan yang diberikan kepadanya. Pada umumnya kerja seorang tenaga kerja antara lain dipengaruhi oleh kecakapan, keterampilan, pengalaman, dan kesungguhan tenaga kerja yang bersangkutan.

\section{3) Tanggung jawab}

Tanggung jawab adalah kesanggupan seorang tenaga kerja dalam menyelesaikan tugas dan pekerjaan yang diserahkan kepadanya dengan sebaikbaiknya dan tepat waktu serta berani memikul resiko atas keputusan yang diambilnya atau tindakan yang dilakukannya.

4) Ketaatan

Yang dimaksud ketaatan adalah kesanggupan seorang tenaga kerja untuk mentaati segala ketetapan, peraturan perundang-undangan dan peraturan kedinasan yang berlaku.

5) Kejujuran

Yang dimaksud dengan kejujuran adalah ketulusan hati seorang tenaga kerja dalam melaksanakan tugas dan pekerjaan serta kemampuan untuk tidak menyalahgunakan wewenang yang telah diberikan kepadanya.

6) Kerjasama
Kerjasama adalah kemampuan seorang tenaga kerja untuk bekerja sama dengan orang lain dalam menyelesaikan suatu tugas dan pekerjaan yang telah ditetapkan.

7) Prakarsa

Prakarsa adalah kemampuan seorang tenaga kerja untuk mengambil keputusan..

8) Kepemimpinan

kepemimpinan adalah kemampuan yang dimiliki seorang tenaga kerja untuk meyakinkan orang lain (tenaga kerja lain) sehingga dapat dikerahkan secara maksimum untuk melaksanakan tugas pokok.

Malayu Hasibuan, (2009:169) mengatakan kepemimpinan (leadership) yang ditetapkan oleh seorang manajer dalam organisasi dapat menciptakan integrasi yang serasi dan mendorong gairah kerja karyawan untuk mencapai sasaran yang maksimal. Kepemimpinan adalah kata benda dari pemimpin (leader). Pemimpin (leader:head) adalah seseorang yang mempergunakan wewenang dan kepemimpinannya, mengarahkan bawahan untuk mengerjakan sebagian pekerjaannya dalam mencapai tujuan organisasi.

Sopiah, (2008:123) membagi dua fungsi penting yang harus ada pada seorang pemimpin, yaitu :

\section{1) Fungsi tugas}

Fungsi ini berhubungan dengan sesuatu yang harus dilaksanakan untuk memilih dan mencapai tujuan-tujuan secara rasional. Adapun fungsi tugas seorang pemimpin adalah:

a. Menciptakan kegiatan

Tugas pemimpin adalah menetapkan deskripsi pekerjaan secara jelas untuk karyawan/bawahannya..

b. Mencari Informasi

Tugas pemimpin adalah mencari informasi tersebut secara cepat, tepat dan akurat.

c. Memberi informasi

Informasi yang telah diperoleh kemudian didistribusikan kepada 
bawahannya sehingga semua karyawan mendapatkan informasi yang dibutuhkannya

d. Memberi pendapat

Tugas pemimpin adalah memberikan pendapat dan nasehat kepada bawahan, baik diminta maupun tidak diminta jika memang dirasa perlu.

e. Menjelaskan

Pemimpin menjelaskan apa aja yang dirasa belum jelas oleh bawahannya, misalnya tentang tugas, kewajiban, dan hak-hak bawahan.

f. Mengoordinasikan

Tugas ini penting karena tanpa koordinasi yang baik yang dilakukan pemimpin maka organisasi bisa tidak dapat berjalan secara efisien dan efektif dalam mencapai tujuan-tujuannya.

g. Meringkaskan

Meringkaskan atau menyimpulkan semua yang telah disepakati sehingga bawahan bisa mencapai pemahaman yang sama tentang sesuatu hal, misalkan tentang kebijakan-bijakan yang diambil organisasi.

h. Menguji kelayakan

Jika organisasi merencanakan untuk melaksanakan berbagai program, terlebih dahulu pemimpin harus menguji layak/tidaknya program tersebut untuk dilaksanakan.

i. Mengevaluasi

Tugas pemimpin yang lain adalah mengevaluasi atau mengendalikan orang atau kegiatan dengan harapan semua kegiatan/orang dalam organisasi bergerak ke tujuan yang telah ditetapkandalam tahap perencanaan.

j. Mendiagnosis

Sebelum persoalan-persoalan muncul ke permukaan, pemimpin terlebih dahulu harus mampu mendiagnosis gejalannya sehingga tindakan preventif bisa dilakukan mengingat tindakan preventif jauh lebih efisien daripada tindakan kuratif.

2) Fungsi Pemeliharaan

Fungsi ini berhubungan dengan kepuasan emosi yang diperlukan untuk mengembangkan dan memelihara kelompok untuk keberadaan organisasi. Adapun fungsi pemeliharaan seorang pemimpin adalah sebagai berikut :

a. Mendorong semangat

Memotivasi karyawan agar selalu bergairah dan bersemangat dalam bekerja.

b. Menetapkan standar

Standar kinerja harus ditetapkan dari awal dan hal ini merupakan tugas pemimpin. Tanpa standar kinerja yang jelas, karyawan tidak akan tahu apakah dia sudah bekerja denga baik atau belum.

c. Mengikuti

Pemimpin tidak boleh lepas tangan begitu saja setelah tugas didistribusikan

d. Mengekpresikan perasaan

Perasaan senang atau tidak senang dengan apa yang dilakukan bawahan perlu diekspresikan si pemimpin dengan baik sehingga bawahan bisa menangkap maksud dan keinginan pemimpinya dengan baik.

e. Mengambil konsensus

Tugas pemimpin adalah mengambil atau menetapkan konsensus walaupun prosesnsya melibatkan banyak orang.

f. Menciptakan keharmonisan

Keharmonisan dalam organisasi perlu dibangun karena hal itu sangat penting. Keharmonisan hubungan antarindividu dalam organisasi, antara atasanbawahan, individu dengan rekan kerja.

g. Mengurangi ketegangan

Ketegangan yang berlebihan akan berdampak negatif terhadap kinerja, baik kinerja individu, kelompok maupun organisasi.

Menurut Malayu S.P. Hasibuan (2009: 118), Kompensasi adalah semua pendapatan yang berbentuk uang, barang langsung atau tidak langsung yang diterima karyawan sebagai imbalan atas jasa yang diberikan kepada perusahaan. Rivai dan Ella (2011:741) kompensasi merupakan sesuatu yang diterima karyawan sebagai pengganti kontribusi jasa mereka pada perusahaan. 
Nawawi (2008:316) membagi jenisjenis kompensasi sebagai berikut :

1. Kompensasi Langsung

Kompensasi langsung adalah penghargaan /ganjaran yang disebut gaji atau upah yang dibayar secara tetap berdasarkan tenggang waktu yang tetap.

\section{Kompensasi Tidak Langsung}

Kompensasi tidak langsung adalah pemberian bagian keuntungan/manfaat lainnya bagi para pekerja di luar gaji atau upah tetap, dapat berupa uang atau barang. Misalnya THR, Tunjangan Hari Natal dan lain-lain..

\section{Insentif}

Insentif adalah penghargaan/ganjaran yang diberikan untuk memotivasi para pekerja agar produktivitasnya tinggi, sifatnya tidak tetap atau sewaktu-waktu.

Menurut Sudimin (2003:5), loyalitas berarti "Kesediaan karyawan dengan seluruh kemampuan, keterampilan, pikiran, dan waktu untuk ikut serta mencapai tujuan perusahaan dan menyimpan rahasia perusahaan serta tidak melakukan tindakantindakan yang merugikan perusahaan selama orang itu masih berstatus sebagai karyawan."

Menurut Anaroga yang dikutip oleh Rukmi,dkk (2012:45) mengemukakan ada beberapa cara yang dapat ditempuh untuk meningkatkan loyalitas kerja, yaitu:

1. Hubungan yang erat antar karyawan,

2. Saling keterbukaan dalam hubungan kerja,

3. Saling pengertian antara pimpinan dengan karyawan,

4. Memperlakukan karyawan tidak sebagai buruh, tetapi sebagai rekan kerja,

5. Pimpinan berusaha menyelami pribadi karyawan secara kekeluargaan,

6. Rekreasi bersama seluruh anggota perusahaan.

\section{METODE}

Penelitian ini dilaksanakan pada Kantor Pemasaran Agency II PT BNI Life Insurance. Populasi sasaran dalam penelitian ini adalah seluruh agen yang memiliki sertifikasi lisensi AAJI dengan masa kerja $\geq$ 1 tahun pada PT. BNI Life Insurance di. Kantor Cabang Pemasaran Agency II yang terdiri dari 15 Kota di Indonesia.

Pengambilan sampel pada penelitian ini diambil secara disproportionate stratified random sampling, yaitu pengambilan sampel dari anggota populasi secara acak dan berstrata tetapi sebagian ada yang kurang proporsional pembagiannya, dilakukan sampling ini apabila anggota populasinya heterogen. Teknik pengambilan sampel menggunakan rumus dari Taro Yamane. Berdasarkan perhitungan sampel, maka sampel yang diambil adalah sebanyak 89 orang responden secara proporsional.

Data penelitian dianalisis dengan menggunakan teknik analisa jalur, Kusnedi dalam Riduwan (2007:2) menyatakan Path analisis digunakan untuk menganaliss pola hubungan antar variabel dengan tujuan untuk mengetahui pengaruh langsung maupun tidak langsung seperangkat variabel bebas (eksogen) terhadap variabel terikat (endogen).

\section{HASIL}

\section{Pengujian SubStruktur 1}

\begin{tabular}{|l|r|r|r|r|r|}
\hline Model & $\begin{array}{c}\text { Sum of } \\
\text { Squares }\end{array}$ & df & Mean Square & F & Sig. \\
\hline 1 Regression & 3310.149 & 2 & 1655.074 & 570.712 & $.000^{\mathrm{a}}$ \\
Residual & 249.402 & 86 & 2.900 & & \\
Total & 3559.551 & 88 & & & \\
\hline
\end{tabular}
a. Predictors: (Constant), KOMPENSASI, KEPEMIMPINAN
b. Dependent Variable: LOY ALITAS AGEN

Tabel diatas adalah anova substruktur 1 yang menunjukkan nilai $F$ sebesar 570.712 dengan nilai signifikan 0,000 .

\begin{tabular}{|l|r|r|r|r|r|}
\hline \multirow{2}{*}{ Model } & \multicolumn{2}{|c|}{$\begin{array}{c}\text { Unstandardized } \\
\text { Coefficients }\end{array}$} & $\begin{array}{c}\text { Standardized } \\
\text { Coefficients }\end{array}$ & & \multirow{2}{*}{ Sig. } \\
\cline { 2 - 5 } & \multicolumn{1}{c|}{$\mathrm{B}$} & Std. Error & \multicolumn{1}{c|}{ Beta } & \multicolumn{1}{c|}{$\mathrm{t}$} & Sig \\
\hline 1 (Constant) & .477 & 1.710 & & .279 & .781 \\
Kepemimpinan & .858 & .039 & .859 & 21.918 & .000 \\
Kompensasi & .130 & .035 & .145 & 3.713 & .000 \\
\hline
\end{tabular}


Tabel diatas adalah Coefficients ${ }^{a}$ substruktur 1 yang menunjukkan nilai " $\mathrm{t}$ " kepemmpinan $\left(\mathrm{X}_{1}\right)$ sebesar 21.918 dengan nilai signifikan 0,000 dan kompensasi $\left(\mathrm{X}_{2}\right)$ sebesar 3.713 dengan nilai signifikan 0,000.

\begin{tabular}{|l|c|r|r|r|}
\hline Model & R & R Square & $\begin{array}{c}\text { Adjusted R } \\
\text { Square }\end{array}$ & $\begin{array}{c}\text { Std. Error of the } \\
\text { Estimate }\end{array}$ \\
\hline 1 & $.964^{\mathrm{a}}$ & .930 & .928 & 1.70294 \\
\hline
\end{tabular}

Tabel summary sub-struktur 1 diatas yang menunjukkan koefisien determinasi atau pengaruh (Rsquare) $=\mathrm{R}^{2}$ sebesar 0,930 .

Memaknai Analisis Jalur Sub-struktur 1

Dari hasil pengolahan data program SPSS pada sub-struktur 1 tersebut terlihat :

\section{Pengujian Secara Simultan (Keseluruhan)}

Uji secara keseluruhan ditunjukkan oleh tabel Anova. Hipotesis statistik dirumuskan sebagai berikut :

Ho : $\mathrm{px}_{3} \mathrm{x}_{1}=\mathrm{px}_{3} \mathrm{x}_{2}=0$

$\mathrm{Ha}: \mathrm{px}_{3} \mathrm{x}_{1}=\mathrm{px}_{3} \mathrm{x}_{2} \neq 0$

Hipotesis dalam bentuk kalimat :

Ho : Kepemimpinan $\left(\mathrm{X}_{1}\right)$ dan kompensasi $\left(X_{2)}\right.$ tidak berpengaruh secara simultan dan signifikan terhadap loyalitas $\left(\mathrm{X}_{3}\right)$.

$\mathrm{Ha}$ : Kepemimpinan $\left(\mathrm{X}_{1}\right)$ dan kompensasi $\left(X_{2}\right)$ berpengaruh secara simultan dan signifikan terhadap terhadap loyalitas $\left(\mathrm{X}_{3}\right)$.

Dari tabel Anova diperoleh nilai $\mathrm{F}$ sebesar 570.712 dengan nilai probabilitas $($ sig $)=0,000$ karena nilai sig $<0,05$ maka keputusan adalah Ho ditolak, artinya kepemimpinan dan kompensasi berpengaruh secara simultan dan signifikan terhadap loyalitas. Dengan demikian pengujian secara individu dapat dilakukan atau dilanjutkan.

\section{Pengujian Secara Individual Sub- Struktur 1}

a. Kepemimpinan Berpengaruh Secara Signifikan Terhadap Loyalitas

Uji secara individual ditunjukkan oleh tabel coefficiesnts sub-struktur 1. Hipotesis penelitian yang akan diuji dirumuskan menjadi hipotesis statistik sebagai berikut :
Ho : $\mathrm{px}_{3} \mathrm{x}_{1}=0$

$\mathrm{Ha}: \mathrm{px}_{3} \mathrm{x}_{1}>0$

Hipotesis dalam bentuk kalimat :

Ho:Kepemimpinan tidak berpengaruh secara signifikan terhadap loyalitas.

Ha:Kepemimpinan berpengaruh secara signifikan terhadap loyalitas.

Secara individual uji statistik yang digunakan adalah uji $\mathrm{t}$ diperoleh nilai $\mathrm{t}$ pada $X_{1}=21,918$ dengan nilai sig 0,000 . Nilai sig $0,000<0,05$, maka Ho ditolak dan Ha diterima, artinya kepemimpinan berpengaruh signifikan terhadap loyalitas agen.

\section{b. Kompensasi Berpengaruh Signifikan Terhadap Loyalitas Agen}

Hipotesis penelitian yang akan diuji dirumuskan menjadi hipotesis statistik sebagai berikut :

Ho: $\mathrm{px}_{3} \mathrm{x}_{2}=0$

$\mathrm{Ha}: \mathrm{px}_{3} \mathrm{x}_{2}>0$

Hipotesis dalam bentuk kalimat:

Ho :Kompensasi tidak berpengaruh secara signifikan terhadap loyalitas agen.

$\mathrm{Ha}$ :Kompensasi berpengaruh secara signifikan terhadap loyalitas agen.

Secara individual uji statistik yang digunakan adalah uji $\mathrm{t}$ diperoleh nilai $\mathrm{t}$ pada $\mathrm{X}_{2}=3,713$. dengan nilai sig 0,000 . Nilai sig 0,000<0,05 maka Ho ditolak dan Ha diterima, artinya kompensasi berpengaruh signifikan terhadap loyalitas agen.

$$
\begin{aligned}
\text { Rsquare } & =\mathrm{R}^{2} \mathrm{X}_{3} \mathrm{X}_{2} \mathrm{X}_{1} \\
& =\left(\mathrm{pyX}_{1}\right) \cdot\left(\mathrm{ry} \mathrm{X}_{1}\right)+\left(\mathrm{pyX}_{2}\right) \cdot\left(\mathrm{ry} \mathrm{X}_{2}\right) \\
& =(0,859) \cdot(0,958)+(0,145) \cdot(0,734) \\
& =0,822922+0,10643 \\
& =0,929352 \quad(0,930) . \quad \text { (tabel. } \\
& \text { Summary Sub-struktur1) }
\end{aligned}
$$

Besar koefisien residu $\varepsilon_{1}=\sqrt{1-0,964}=$ 0,189 Dengan demikian didapat diagram jalur sub-struktur 1 sebagai berikut :

\section{Sub-Struktur 1}

$\mathrm{X}_{3}=\mathrm{px}_{3} \mathrm{x}_{1}+\mathrm{px}_{3} \mathrm{x}_{2}+\mathrm{px}_{3} \varepsilon_{1}$ 
pengaruh $(R$ square $)=0,896$

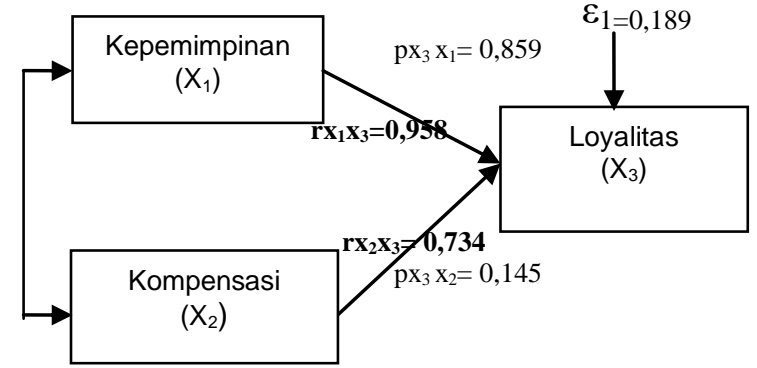

Gambar.4.5 Diagram Jalur Sub-Struktur 1

Dengan persamaan struktural sub-struktural 1 sebagai berikut :

$\mathrm{X}_{3}=\mathrm{px}_{3} \mathrm{x}_{1} \mathrm{X}_{1}+\mathrm{px}_{3} \mathrm{x}_{2} \mathrm{X}_{2}+\varepsilon_{1}$

$\mathrm{x}_{3}=0,859 \mathrm{X}_{1}+0,145 \mathrm{X}_{2}+0,189$

\section{Menguji Sub-Struktur 2}

\begin{tabular}{|c|c|c|c|c|c|}
\hline \multicolumn{6}{|c|}{ ANOVA $^{b}$} \\
\hline Model & $\begin{array}{l}\text { Sum of } \\
\text { Squares }\end{array}$ & $\mathrm{df}$ & $\begin{array}{c}\text { Mean } \\
\text { Square }\end{array}$ & $\mathrm{F}$ & Sig. \\
\hline $1 \quad$ Regression & 3944.668 & 3 & 1314.889 & 244.002 & $.000^{\mathrm{a}}$ \\
\hline Residual & 458.051 & 85 & 5.389 & & \\
\hline Total & 4402.719 & 88 & & & \\
\hline
\end{tabular}

a. Predictors: (Constant), Loyalitas Agen, Kompensasi,

$$
\text { Kepemimpinan }
$$

b. Dependent Variable: Kinerja Agen

Tabel anova sub-struktur 2 menunjukkan nilai $\mathrm{F}$ sebesar 244.002 dengan Signifikan 0,000.

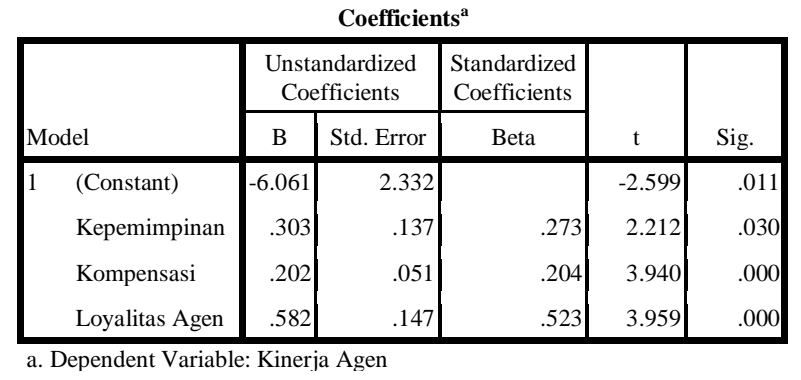

Tabel coefficients sub- struktur 2 yang menunjukkan nilai $\mathrm{t}$ kepemimpinan $(\mathrm{X} 1)=$ 2,212, dengan signifikansi 0,030 ,kompensasi $(X 2)=3,940$ dengan nilai signifikansi 0,000 dan loyalitas agen $(\mathrm{X} 3)=3,959$ dengan nilai signifikansi 0,000 .

\begin{tabular}{|l|c|r|r|r|}
\hline Model & R & R Square & $\begin{array}{c}\text { Adjusted R } \\
\text { Square }\end{array}$ & $\begin{array}{c}\text { Std. Error of the } \\
\text { Estimate }\end{array}$ \\
\hline 1 & $.947^{\mathrm{a}}$ & .896 & .892 & 2.32139 \\
\hline
\end{tabular}

Pada tabel summary sub-struktur 2 yang menunjukkan koefisien determinasi atau

\section{Memaknai Analisis Jalur Sub-Struktur 2}

Dari hasil pengolahan data program SPSS 17, pada sub-struktur 2 tersebut terlihat pada tabel koefisien jalur diperoleh sebagai berikut :
1. Pengujian secara simultan (keseluruhan)

Uji secara keseluruhan ditunjukkan oleh tabel Anova hipotesis statistik dirumuskan sebagai berikut :

Ho : $\mathrm{pyX}_{1}=\mathrm{py}_{2}=\mathrm{pyX}_{3}=0$

$\mathrm{Ha}: \operatorname{pyX}_{1}=\operatorname{pyX}_{2}=\operatorname{pyX}_{3} \neq 0$

Hipotesis dalam bentuk kalimat :

Ho :Kepemimpinan kompensasi dan loyalitas agen tidak berpengaruh secara simultan dan signifikan terhadap kinerja agen

$\mathrm{Ha}$ :Kepemimpinan kompensasi dan loyalitas agen berpengaruh secara simultan dan signifikan terhadap kinerja agen

Dari tabel Anova diperoleh nilai $\mathrm{F}$ sebesar 244,002 dengan nilai probabilitas $($ sig $)=0,000$ karena nilai sig $<0,05$ maka keputusan adalah Ho ditolak, artinya kepemimpinan, kompensasi dan loyalitas agen berpengaruh secara simultan dan signifikan terhadap kinerja agen. Dengan demikian pengujian secara individu dapat dilakukan atau dilanjutkan.

2. Pengujian secara individual sub-struktur 2

\section{a. Kepemimpinan berpengaruh secara signifikan terhadap kinerja agen}

Uji secara individual ditunjukkan oleh tabel. coefficiesnts sub-struktur 2. Hipotesis penelitian yang akan diuji dirumuskan menjadi hipotesis statistik sebagai berikut :

Ho : $\mathrm{pyX}_{1}=0$

Ha : pyX $_{1}>0$

Hipotesis dalam bentuk kalimat :

Ho :Kepemimpinan tidak berpengaruh secara signifikan terhadap kinerja agen 
Ha:Kepemimpinan berpengaruh secara signifikan terhadap kinerja agen

Secara individual uji statistik yang digunakan adalah uji $\mathrm{t}$ pada tabel 4.18. diperoleh nilai $\mathrm{t}\left(\mathrm{X}_{1}\right)=0,273$ dengan nilai sig 0,030. Nilai sig $0,030<0,05$, maka Ho ditolak dan $\mathrm{Ha}$ diterima, artinya kepemimpinan berpengaruh signifikan terhadap kinerja agen.

\section{b. Kompensasi berpengaruh signifikan terhadap kinerja agen.}

Hipotesis penelitian yang akan diuji dirumuskan menjadi hipotesis statistik sebagai berikut :

Ho : $\mathrm{pyX}_{2}=0$

$\mathrm{Ha}:$ py $_{2}>0$

Hipotesis dalam bentuk kalimat :

Ho :Kompensasi tidak berpengaruh secara signifikan terhadap kinerja agen

Ha :Kompensasi berpengaruh secara signifikan terhadap kinerja agen

Secara individual uji statistik yang digunakan adalah uji t. diperoleh nilai $\mathrm{t} \mathrm{X}_{2}=$ 0,204 . dengan nilai sig 0,000 . Nilai sig 0,000 $<$ 0,05 maka Ho ditolak dan Ha diterima, artinya Konpensasi berpengaruh secara signifikan terhadap kinerja agen

\section{c. Loyalitas agen berpengaruh secara signifikan terhadap kinerja agen}

Hipotesis penelitian yang akan diuji dirumuskan menjadi Hipotesis statistik sebagai berikut :

Ho : pyX $_{3}=0$

$\mathrm{Ha}:$ py $_{3}>0$

Hipotesis dalam bentuk kalimat :

Ho : Loyalitas agen tidak berpengaruh secara signifikan terhadap kinerja agen

$\mathrm{Ha}$ : Loyalitas agen berpengaruh secara signifikan terhadap kinerja agen

Secara individual uji statistik yang digunakan adalah uji t. Diperoleh nilai $\mathrm{t}_{3}=$ 0,523 dengan nilai sig 0,000 Nilai sig 0,000 > 0,05 maka Ho diterima dan Ha ditolak, artinya loyalitas agen berpengaruh secara signifikan terhadap kinerja agen
Berdasarkan hasil analisis jalur substruktur $2\left(\mathrm{X}_{1}, \mathrm{X}_{2}\right.$, dan $\mathrm{X}_{3}$ dan $\left.\mathrm{Y}\right)$ yang terlihat pada tabel 4.18. koefisien masingmasing diperoleh nilai :

a. pyX $_{1}=$ beta $=0,273(\mathrm{t}=2,212$ dan probabilitas sig $=0,030$ )

b. pyX $\mathrm{X}_{2}=$ beta $=0,204(\mathrm{t}=3,940$ dan probabilitas sig $=0,000$ )

c. pyX $_{3}=$ beta $=0,523(\mathrm{t}=3,959$ dan probabilitas sig $=0,000$ )

Besarnya koefisien determinan (pengaruh) $\mathrm{X}_{1}, \mathrm{X}_{2}$, dan $\mathrm{X}_{3}$ secara simultan terhadap Y sebesar :

$$
\begin{aligned}
\text { Rsquare }= & \mathrm{R}^{2} \mathrm{YX}_{3} \mathrm{X}_{2} \mathrm{X}_{1} \\
= & \left(\mathrm{pyX}_{1}\right) \cdot\left(\mathrm{ryX}_{1}\right)+\left(\mathrm{pyX}_{2}\right) \cdot\left(\mathrm{ryX}_{2}\right)+ \\
& \left(\mathrm{pyX}_{3}\right) \cdot\left(\mathrm{ryX}_{3}\right) \\
= & (0,273) \cdot(0,914)+(0,204) \cdot(0,775) \\
& \quad+(0,523) \cdot(0,934) \\
= & 0,249522+0,1581+0,488482 \\
= & 0,8961
\end{aligned}
$$

Dan besar koefisien residu $\varepsilon_{2}=\sqrt{1-0,8961}$ $=0,3223$.

Berdasarkan hasil dari koefisien jalur pada sub-struktur 1 dan sub-struktur 2 maka dapat digambarkan secara keseluruhan yang menggambarkan hubungan kausal empiris antar variabel $X_{1}, X_{2}$, dan $X_{3}$ terhadap $Y$ sebagai berikut :

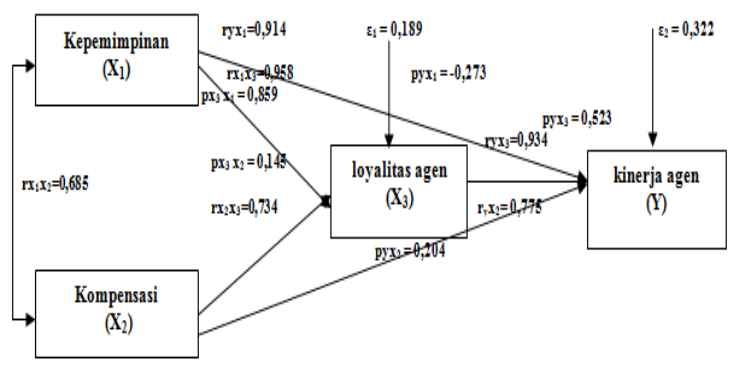

Gambar 1

Hubungan Kausal Empiris Variabel $\mathrm{X}_{1}, \mathrm{X}_{2}$ dan $\mathrm{X}_{3}$ terhadap $\mathrm{Y}$ 
Tabel 4 Koefisien jalur, pengaruh langsung, pengaruh tidak langsung, pengaruh total dan kepemimpinan (X1), kompensasi (X2) dan loyalitas agen (X3) terhadap kinerja agen(Y).

\begin{tabular}{|c|c|c|c|c|c|}
\hline \multirow{2}{*}{$\begin{array}{c}\text { Variab } \\
\text { el }\end{array}$} & \multirow{2}{*}{$\begin{array}{c}\text { Koefisie } \\
\text { n Jalur }\end{array}$} & \multicolumn{3}{|c|}{ Pengaruh } & \multirow{2}{*}{$\begin{array}{c}\text { Pengaru } \\
\text { h } \\
\text { Bersam } \\
\text { a }\left(\mathrm{R}^{2}{ }_{\mathrm{YX}}\right)\end{array}$} \\
\hline & & Langsung & $\begin{array}{c}\text { Tidak } \\
\text { Langsun } \\
\mathrm{g} \\
\text { melalui } \\
\mathrm{X}_{3}\end{array}$ & $\begin{array}{c}\text { Tota } \\
1\end{array}$ & \\
\hline $\mathrm{X}_{1}$ & 0,273 & 0,273 & & 0,273 & \\
\hline $\mathrm{X}_{1}$ & 0,273 & 0,273 & 0,449 & 0.722 & \\
\hline $\mathrm{X}_{2}$ & 0,204 & 0,145 & 0,076 & 0,221 & \\
\hline $\mathrm{X}_{3}$ & 0,523 & 0,523 & & 0,523 & \\
\hline$\overline{\varepsilon_{1}}$ & 0,189 & $\begin{array}{l}0,189^{2}=0.0 \\
36\end{array}$ & & & \\
\hline$\varepsilon_{2}$ & 0,322 & $\begin{array}{l}0,322^{2}=0,1 \\
04\end{array}$ & & & \\
\hline $\begin{array}{r}X_{1}, X_{2} \\
\text { dan } X_{3}\end{array}$ & & & & & 0,896 \\
\hline
\end{tabular}

Dengan persamaan struktural substruktural 2 sebagai berikut:

$Y=\operatorname{pyx}_{1} X_{1}+\operatorname{pyx}_{2} X_{2}+\operatorname{pyx}_{3} X_{3}+p y \varepsilon_{2}$ dan $\mathrm{R}^{2} \mathrm{y}\left(\mathrm{x}_{1} \mathrm{x}_{2} \mathrm{x}_{3}\right)$

$\mathrm{Y}=0,273 \mathrm{X}_{1}+0,204 \mathrm{X}_{2}+0,523 \mathrm{X}_{3}+0,322$ dan 0.896

\section{PEMBAHASAN}

Hipotesis 1 yaitu "kepemimpinan berpengaruh signifikan terhadap loyalitas agen pada PT BNI Life Insurance Kantor Pemasaran Agency II". Dari hasil pengolahan data diketahui besarnya kepemimpinan $\left(\mathrm{X}_{1}\right)$ terhadap loyalitas agen $\left(\mathrm{X}_{3}\right)$ dinyatakan dengan koefisien jalur sebesar 0,859. Ini menunjukkan bahwa kepemimpinan yang ada pada PT BNI Life Insurance Kantor Pemasaran Agency II sangat berperan terhadap loyalitas agen. Sedangkan untuk menyatakan besar kecilnya kontribusi (sumbangan) kepemimpinan terhadap loyalitas agen $=r^{2}$ x $100 \%$ atau $0,859 \times 100 \%=85,9 \%$ sedangkan sisanya $14,1 \%$ ditentukan oleh variabel lain. Hasil penelitian ini memberikan keterangan bahwa variabel kepemimpinan memberikan pengaruh yang kuat terhadap loyalitas agen.

Hipotesis 2 yaitu kompensasi berpengaruh signifikan terhadap loyalitas agen pada PT BNI Life Insurance Kantor Pemasaran Agency II. Dari hasil pengolahan data diketahui besarnya kompensasi $\left(\mathrm{X}_{2}\right)$ terhadap loyalitas agen $\left(\mathrm{X}_{3}\right)$ dinyatakan dengan koefisien jalur sebesar 0,145. Ini menunjukkan bahwa kompensasi yang ada pada PT BNI Life Insurance Kantor Pemasaran Agency II juga berperan terhadap loyalitas agen. Sedangkan untuk menyatakan besar kecilnya kontribusi (sumbangan) kepemimpinan terhadap loyalitas agen $=\mathrm{r}^{2} \mathrm{x}$ $100 \%$ atau $0,145 \times 100 \%=14,5 \%$ sedangkan sisanya $85,9 \%$ ditentukan oleh variabel lain. Hasil penelitian ini memberikan keterangan bahwa variabel kompensasi memberikan pengaruh terhadap loyalitas agen.

Hipotesis 3 yaitu kepemimpinan berpengaruh terhadap kinerja agen pada PT BNI Life Insurance Kantor Pemasaran Agency II. Dari hasil pengolahan data diketahui besarnya kepemimpinan $\left(\mathrm{X}_{1}\right)$ terhadap kinerja agen (Y) dinyatakan dengan koefisien jalur sebesar 0,273 Ini menunjukkan bahwa kepemimpinan yang ada pada PT BNI Life Insurance Kantor Pemasaran Agency II juga berperan positif terhadap kinerja agen. Sedangkan untuk menyatakan besar kecilnya kontribusi (sumbangan) kepemimpinan terhadap kinerja agen $=r^{2} \times 100 \%$ atau $0,273 \times 100 \%$ $=27,3 \%$ Hasil penelitian ini memberikan keterangan bahwa variabel kepemimpinan memberikan berpengaruh positif terhadap kinerja agen.

Hipotesis 4 yaitu kompensasi berpengaruh terhadap kinerja agen pada PT BNI Life Insurance Kantor Pemasaran Agency II. Dari hasil pengolahan data diketahui besarnya kompensasi $\left(\mathrm{X}_{2}\right)$ terhadap kinerja agen (Y) dinyatakan dengan koefisien jalur sebesar 0,204. Ini menunjukkan bahwa kompensasi yang ada pada BNI Life Insurance Kantor Pemasaran Agency II juga berpengaruh terhadap kinerja agen. Sedangkan untuk menyatakan besar kecilnya kontribusi (sumbangan) kompensasi terhadap kinerja agen $=r^{2} \times 100$ $\%$ atau $0,204 \times 100 \%=20,4 \%$, sedangkan 
sisanya sebesar 79,6 \% dipengaruhi oleh faktor lain. Hasil penelitian ini memberikan keterangan bahwa variabel kompensasi berpengaruh terhadap kinerja agen.

Hipotesis 5 yaitu: loyalitas berpengaruh terhadap kinerja agen pada PT BNI Life Insurance Kantor Pemasaran Agency II. Dari hasil pengolahan data diketahui besarnya loyalitas agen $\left(\mathrm{X}_{3}\right)$ terhadap kinerja agen (Y) dinyatakan dengan koefisien jalur sebesar 0,523. Ini menunjukkan bahwa loyalitas agen yang ada pada PT BNI Life Insurance Kantor Pemasaran Agency II berpengaruh terhadap kinerja agen. Sedangkan untuk menyatakan besar kecilnya kontribusi (sumbangan) loyalitas agen terhadap kinerja agen $=\mathrm{r}^{2} \mathrm{x}$ $100 \%$ atau $0,523 \times 100 \%=52,3 \%$, Hasil penelitian ini memberikan keterangan bahwa variabel loyalitas agen sangat berpengaruh terhadap kinerja agen.

Pengaruh langsung $\mathrm{X} 1$ terhadap $\mathrm{Y}$ sebesar $=\left(\right.$ pyx $\left._{1}\right) \cdot\left(\right.$ pyx $\left._{1}\right)=(0,273) .(0,273)=$ 0,075 , dan pengaruh langsung $\mathrm{X} 2$ terhadap $\mathrm{Y}$ sebesar $\left(\mathrm{pyx}_{2}\right) \cdot\left(\mathrm{pyx}_{2}\right)=(0,204) \cdot(0,204)=$ 0,042 . Sedangkan pengaruh tidak langsung $\mathrm{X} 1$ terhadap $\mathrm{Y}$ melalui $\mathrm{X}_{3}$ sebesar $\left(\mathrm{pX}_{3} \mathrm{X}_{1}\right) \cdot\left(\mathrm{PyX}_{3}\right)=(0,859) \cdot(0,523)=0,449$. Dengan demikian pengaruh total $\mathrm{X}_{1}$ terhadap $\mathrm{Y}$ adalah sebesar 0,524. Selanjutnya pengaruh tidak langsung $X_{2}$ terhadap $Y$ melalui $\mathrm{X}_{3}$ terhadap $\mathrm{Y}$ adalah sebesar $\left(\mathrm{pX}_{3} \mathrm{X}_{2}\right) \cdot\left(\mathrm{PyX}_{3}\right)=(0,145) \cdot(0,523)=0,076$ Dengan demikian pengaruh total $\mathrm{X}_{2}$ terhadap Y adalah sebesar 0,118.

\section{KESIMPULAN}

Hasil pengolahan data program SPSS versi 17 pada sub-struktur 1 secara simultan (keseluruhan) kepemimpinan dan kompensasi berpengaruh secara simultan dan signifikan terhadap loyalitas agen. Sedangkan secara individual kepemimpinan berpengaruh signifikan terhadap loyalitas agen dan kompensasi berpengaruh signifikan terhadap loyalitas agen. Pada Pengujian substruktur 2 secara simultan (keseluruhan) kepemimpinan, kompensasi dan loyalitas agen berpengaruh secara simultan dan signifikan terhadap kinerja agen. Pengujian secara individual sub-struktur 2 diperoleh kepemimpinan berpengaruh signifikan terhadap kinerja agen, kompensasi berpengaruh secara signifikan terhadap kinerja agen, loyalitas agen berpengaruh secara signifikan terhadap kinerja agen.

Dari hasil pengolahan data diketahui besar kecilnya kontribusi (sumbangan) kepemimpinan terhadap loyalitas agen 85,9 $\%$ sedangkan kontribusi (sumbangan) kompensasi terhadap loyalitas agen 14,5\%. Besarnya kontribusi kepemimpinan $\left(\mathrm{X}_{1}\right)$ terhadap kinerja agen (Y) dinyatakan dengan koefisien jalur sebesar 27,3\%. kompensasi $\left(\mathrm{X}_{2}\right)$ terhadap kinerja agen $(\mathrm{Y})$ sebesar $20,4 \%$ dan loyalitas agen $\left(X_{3}\right)$ terhadap kinerja agen (Y) sebesar 52,3\%.

Dari hasil perhitungn diketahui bahwa pada sub-struktur 1, kepemimpinan lebih berpengaruh dibandingkan dengan kompensasi terhadap loyalitas agen. Sedangkan pada sub-struktur 2, loyalitas agen lebih berpengaruh terhadap kinerja agen dibandingkan dengan kepemimpinan dan kompensasi.

\section{DAFTAR RUJUKAN}

Adiwibowo, A. Suyunus.2012. Kepemimpinan dan Loyalitas Terhadap Kinerja Karyawan RSJ Surabaya, Jurnal Manajemen Bisnis, Volume 2 No.01 Edisi April. Surabaya.

Alimuddin, Wahyuni.2012. Pengaruh Kompensasi Terhadap Produktivitas Karyawan Pada PT.Bakrie Telecom Area Makassar, Universitas Hasanuddin Makassar.

Dubrin, A. J. 2001. Leadership: Research Findings, Practices, and Skills, Third Edition. Houghton Mifflin Company: Boston.

Handoko, Hani T. 2001. Manajemen, BPFE Yogyakarta.

Hasibuan, Malayu S.P. 2009. Manajemen Sumber Daya Manusia: Dasar Kunci 
Keberhasilan, Haji Masagung, Jakarta. 2011. Manajemen Sumber Daya Manusia (Edisi Revisi). Bumi Aksara: Jakarta.

Hariandja, Marihot Tua Efendi, 2002. Manajemen Sumber Daya Manusia: Pengadaan Pengembangan Pengkompensasian dan Peningkatan Produktivitas Pegawai. PT Grasindo. Jakarta.

Luthans, Fred.2002. Organizational Behavior, Ninth Edition.McGraw-Hill International Editions,Singapore.

Mangkunegara, AA Anwar Prabu, 2001. Manajemen Sumber Daya Manusia Perusahaan.PT. Remaja Rosdakarya, Bandung.

Malthis, Robert L dan Jackson, Jhon L. 2006. Manajemen Sumber Daya Manusia. Edisi Bahasa Indonesia. Salemba Empat, Jakarta.

Nawawi, Hadari. 2002. Manajemen Sumber Daya Manusia untuk Bisnis yang Kompetitif ,Gajah Mada University Press. Yogyakarta.

Northouse, P.G.2003. Leadership: Theory and Practice, Third Edition.Response Book. New Delhi.

Oei, Istijanto. 2010. Riset Sumber Daya Manusia. PT. Gramedia Pustaka Utama. Jakarta.

Riberu. J, 2003. Dasar-Dasar Kepemimpinan, CV. Pedoman Ilmu Jaya, Jakarta.

Riduwan.2010. Metode dan Teknik Menyusun Tesis, Alfabeta. Bandung.

Rivai, Veithzal dan Deddy Mulyadi 2011. Kepemimpinan dan Perilaku Organisasi, Edisi Ketiga, Cetakan ke 8, Rajawali Pers Divisi Buku Perguruan Tinggi ,RajaGrafindo Persada, Jakarta.

Ella Jauvani Sagala, 2011. Manajemen Sumber Daya Manusia Untuk Perusahaan dari Teori ke Praktik,
Edisi Kedua, Cetakan ke 4, RajaGrafindo Persada. Jakarta.

Rohmini, Siti. 2011. Hubungan Pemberian Kesejahterahan dan Suasana Kerja dengan Loyalitas Kerja Perawat di Rumah Sakit Islam Muhammadiyah Kendal. Universitas Muhammadiyah, Semarang..

Sastrohardiwiryo, siswanto, 2005. Manajemen Tenaga Kerja Indonesia Pendekatan Administratif dan Operasional, Bumi Aksara, Jakarta.

Simamora, Henry, 2004. Manajemen Sumber Daya Manusia. Penerbit STIE YKPN. Yogyakarta.

Sopiah, 2008. Perilaku Organisasi, Andi, Yogyakart.,

Sutrisno, Edy, 2010. Budaya Organisasi, Kencana Prenada Media Group. Jakarta.

Sudimin, Theo. 2003. Whistleblowing: Dilema Loyalitas dan Tanggung Jawab Publik. Manajemen \& Usahawan Indonesia, 32(11). 3-8.

Tien Martini, Rukmi, dkk, 2012. Faktorfaktor Penentu yang Mempengaruhi Loyalitas Kerja Karyawan, Jurnal, Vol .13, No 1, Juni. Universitas Muhammadiyah Surakarta.

Tika, Pabundu, Moh, 2010. Budaya Organisasi dan Peningkatan Kinerja Perusahaan, PT. Bumi Aksara. Jakarta.

Utomo, Budi, 2002. Menentukan faktorfaktor kepuasan kerja dan tingkat pengaruh kepuasan kerja terhadap loyalitas karyawan PT P. Jurnal Manajemen \& Kewirausahaan,Vol. 7 (2, 171-188).

Winardi, 2004. Manajemen Sumber Daya Manusia, Grafiti, Jakarta. 